Annals of Warsaw University of Life Sciences - SGGW

Land Reclamation No 38, 2007: 105-113

(Ann. Warsaw Univ. of Life Sci. - SGGW, Land Reclam. 38, 2007)

\title{
Hydrological background of the dune slack vegetation in the Kiskunság
}

\author{
KATALIN MARGÓCZI ${ }^{1}$, JÁNOS SZANYI $^{2}$, ESZTER ARADI ${ }^{1}$, \\ BERTALAN BUSA-FEKETE ${ }^{3}$ \\ ${ }^{1,3}$ Department of Ecology, University of Szeged, Hungary \\ ${ }^{2}$ Hungarian Geological Survey, Szeged, Hungary \\ ${ }^{3}$ Department of Mineralogy, Petrology and Geochemistry, University of Szeged, Hungary
}

\begin{abstract}
Hydrological background of the dune slack vegetation in the Kiskunság. In the southern Kiskunság the natural vegetation (sand steppe, fen meadow, fen or marsh and alkali vegetation) survived in the dune slack meadows (DSM). The vegetation of these meadows are species rich, and has high natural value. The main goal of this study is to reveal the hydrological backgrounds in order to help conservation of the natural values. Two DSM was investigated (MM and CS site): vegetation was sampled, observation wells were planted, and data of other wells in similar position were used to describe the hydrological background of the vegetation. The characteristic groundwater level of the same vegetation type in the relatively wet 2005 year was higher in MM site, than in the CS site. We suppose, that this is a consequence of the earlier vegetation change because of the strong decrease of groundwater level in the region of MM site. The model of hydraulic flow system showed that the DSMs are situated in hydraulic discharge zones. We suppose, that an upward flow plays an important role in development of alkali vegetation in the CS site. Cross-correlation coefficient between groundwater and previous precipitation indicated a quick infiltration of rainwater into the soil, and a pressure front of the groundwater stream reaching the area of well after 22-23 days after rainfall. The quick and strong regional hydrological changes, especially the decrease of groundwater level would endanger this valuable vegetation, but certain resistance and plasticity of it is rather possible.
\end{abstract}

Key words: dune slack vegetation, hydrological conditions, ground water, MODFLOW model.

\section{INTRODUCTION}

Kiskunság is an inland sand dune area in Hungary between the River Danube and Theiss. The natural vegetation is a forest steppe here, but on the map of the First Military Survey in 1782-1785 the whole studied area is grassland (puszta) with sand dunes and wet areas. In the southerneastern part of the sand tableland the natural vegetation (sand steppe, fen meadow and salt marsh) survived in the dune slack meadows (DSM), while the area between them were ploughed, and used for agriculture from the 19th century (Margóczi, 2001). The vegetation of these remnant meadows are species rich, and has high natural value (Aradi et al., 2006). Knowledge of groundwater systems is one of the most important aspects in the protection of ecologically valuable areas (Batelaan et al., 2003). In the last decades a considerable groundwater decrease was detected in the Kiskunság (Major and Neppel, 1988), and perhaps the vegetation of dune slack meadows are endangered because of this, but there is no evidence of this in the scientific literature. Information about the hydrological conditions of dune slack vegetation is necessary to 
understand the natural processes, and to plan habitat management or restoration. The main goal of this study is to reveal the connection of hydrological backgrounds and vegetation pattern. The following questions were asked during the study:

- What kind of groundwater level is necessary to maintain the different vegetation types of the dune slack meadows?

- What sort of groundwater flow system exist in the region?

- What kind of hydrological factors forms fen and alkali vegetation in the same DSM?

- Does the regional decrease of the groundwater level in the last decades manifest in the vegetation changes of the studied sites?

\section{METHODS}

Two pieces of about 100 ha large dune slack meadows were chosen for detailed botanical and hydrogeological investigation: the Csipak-semlyék (CS), and the so called "Magic" Meadow (MM) (this nickname were given by botanists, because of its unusual richness in protected plants). Both area are part of the Natura 2000 network.

Two observation wells were planted in both study sites in September 2004. The filter is between 5 and $8 \mathrm{~m}$ in the wells, and the water level is detected automatically in every 10 minutes. The data were evaluated until November 2005. In order to reveal the effects of precipitation on the groundwater, geostatistical analyses were performed. The software Statgraphics was used for cross-correlation analysis of daily precipitation and groundwater level data.

Pressure gradients were computed from the data of deep observation wells in similar position than the study sites in graphical way (Tóth and Almási, 2001). We used the data of the Hungarian Inventory of Wells. The model of hydraulic flow system was computed by Processing MODFLOW (Chiang and Kinzelbach, 1996).

The vegetation was sampled along a $500 \mathrm{~m}$ and a $380 \mathrm{~m}$ long transect in site $\mathrm{CS}$ and in site MM respectively. The transects were positioned approximately along the line determined by observation wells, crossing stands of the relevant vegetation types. In $5 \times 5 \mathrm{~m}$ quadrates coenological relevés were made by detecting the cover rates of plant species in June, 2005.

The plant species were grouped according to their local habitat preferences using the national habitat classification system (Fekete et al., 1997). The total percent cover of these species groups were counted in the whole sample area (in the two transects). The occurring habitats were classified into the following four larger categories: fen \& marsh, wet meadow, steppe, alkali vegetation. Every relevé was categorized into one of the main habitat types: if the cover value of the species belonging to the certain main habitat type was higher than $50 \%$. If there were no such dominant species group, the relevé was determined as 'transitional'.

The minimum, maximum monthly averages and whole year average groundwaterleveloftheindividual relevés were counted by spatial extrapolation of the measured values in the wells, using 
the elevation data of the individual plots. The elevation data of the plots were measured by levelling instrument (theodolite). The average groundwater level of the relevés classified by the main vegetation type were computed and compared in both study sites. We used t-probe for comparison of the data sets of the CS and MM sites.

\section{RESULTS}

\section{Description of the dune slack vegetation}

The dune slacks in the southern Kiskunság usually contains small sand hills within the depression, so a vegetation zonation can develop in them. On the top of the sand hills there are Pannonic sand steppes
(Astragalo-Festucetum

rupicolae), at lower elevation, on the side of the sand hills a fen meadow (Molinietum) develops, and on the deepest areas fen or marsh vegetation occurs. If there is a salt effect, Molinietum is replaced by alkali meadow (Agrostio caricetum distantis) and in the deepest areas salt marsh or sometimes alkali lakes can be found. The transitional zones are often very wide.

The studied MM site is near to the top of the large sand tableland between 102 and $104 \mathrm{~m}$ elevation above Baltic Sea level, rather on a "terrace" than in a depression. The CS site is on lower level, toward to the feet of the tableland between 91.5 and $93.5 \mathrm{~m}$, and really in a depression (Fig. 1). The main difference of the vegetation in the two studied site, than in CS site the salt effect is

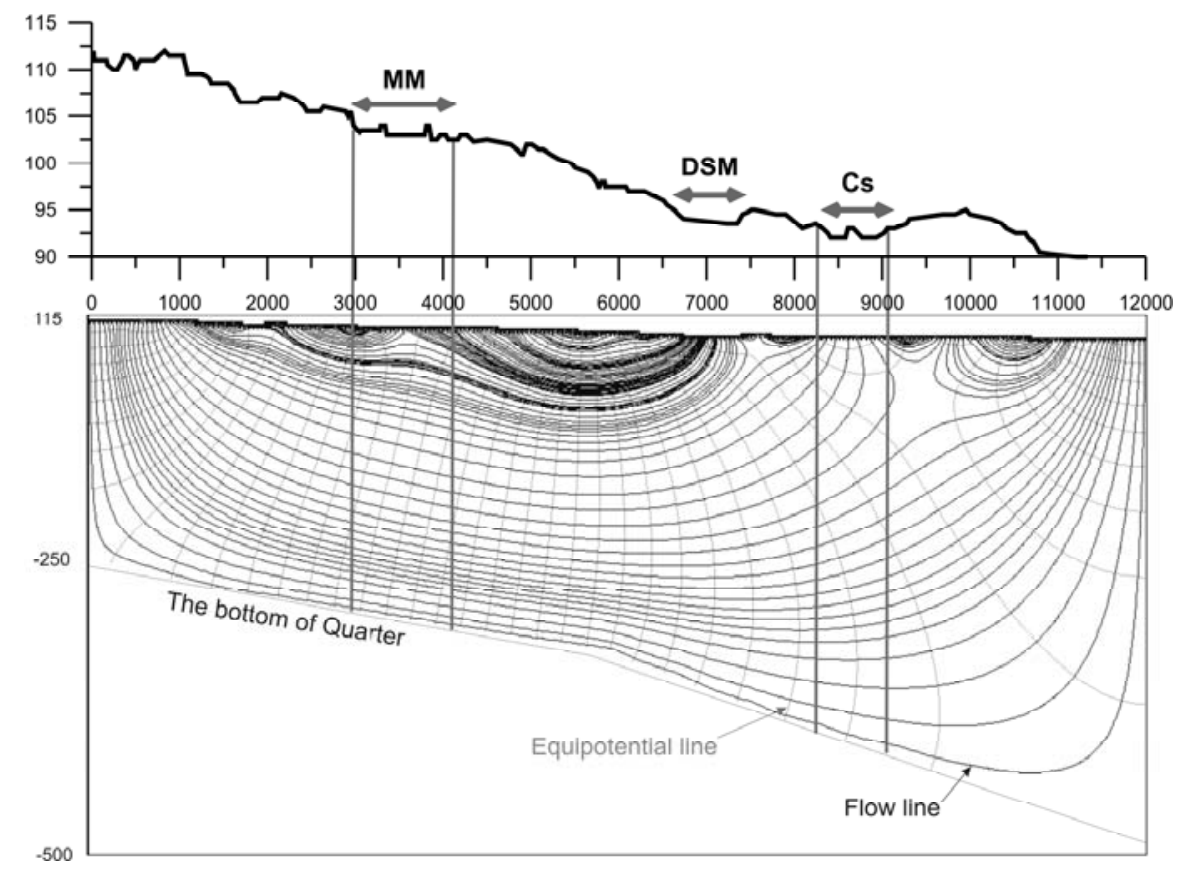

FIGURE 1. Model of hydraulic flow system with exaggerated groundwater-level line (black: flow lines, grey: equipotential lines). MM and CS: study sites, DSM: similar dune slack meadow, not studied yet 
considerable, alkali vegetation occurs, but the vegetation shows no salt effect in the MM site. The proportion of the species groups determined by their regional habitat preferences are given in Table 1.

The number of protected plant species in national level is 24 in the MM site (e.g. Gladiolus palustris, Bulbocodium vernum, Stipa borysthenica, Iris sibirica, Anacamptis pyramidalis) and there are 20 protected species in the CS site (e.g. Ophrys sphecodes, Cirsium brachycephalum, Crocus reticulatus, Gentiana pneumonanthe, Anacamptis palustris).

\section{Groundwater table level of the main vegetation types}

The precipitation in 2005 was $784 \mathrm{~mm}$ in Hungary (average); it is $20 \%$ higher than the average between 1961-1990 (www. met.hu). The local measurement in the observation wells made it possible to determine the characteristic groundwater levels of the main vegetation types during the study period. The lowest monthly average was detected in October 2004, and the highest in April 2005.

The characteristic groundwater levels of the main vegetation types differ in the two study sites. $20-40 \mathrm{~cm}$ higher groundwater level belongs to the same vegetation type in the MM site, than in the CS site. The difference is significant in most of the cases (Tab. 2). In the driest

TABLE 1. Proportion of species groups determined by their regional habitat preferences in the study plots (transects) of the studied CS and MM sites, and the main habitat categories used in hydrological evaluation

\begin{tabular}{|l|c|c|c|}
\hline & \multicolumn{2}{|c|}{$\begin{array}{c}\text { Proportion of species groups } \\
\text { (percent cover) }\end{array}$} & \\
\hline $\begin{array}{l}\text { National habitat categories and their } \\
\text { codes }\end{array}$ & MM & CS & Main categories \\
\hline Free-floating vegetation (A1) & 9.15 & 0 & Fen, marsh \\
\hline Reedbed (B3) & 15.8 & 14.9 & Fen, marsh \\
\hline Marsh vegetation (B3,4,5) & 5.6 & 0.94 & Fen, marsh \\
\hline Large sedges (B4,5) & 14.7 & 1.89 & Fen, marsh \\
\hline Marsh meadow (D4) & 7.2 & 8.75 & Wet meadow \\
\hline Molinietum (D2) & 21.1 & 24.5 & Wet meadow \\
\hline Molinietum $\times$ steppe (D $\times$ H) & 6.13 & 7.25 & Transition \\
\hline Pannonic sand steppe* (H5b) & 17.2 & 9.63 & Steppe \\
\hline Salt marsh* (B6) & 0.03 & 1.3 & Alkali vegetation \\
\hline Salt steppe* (F1) & 0.01 & 6.13 & Alkali vegetation \\
\hline Salt meadow* (F2) & 0.63 & 14 & Alkali vegetation \\
\hline Puccinellietum* (F4) & 0 & 0.25 & Alkali vegetation \\
\hline Weed and indifferent & 1.9 & 0.29 & \\
\hline
\end{tabular}


TABLE 2. Yearly average, minimum and maximum monthly averages groundwater levels belonging to the different vegetation types in the MM and CS study sites in 2005.

\begin{tabular}{|l|c|c|c|c|c|c|c|c|c|c|c|}
\hline \multirow{2}{*}{ Vegetation type } & \multicolumn{3}{|c|}{ Average $(\mathrm{cm})$} & \multicolumn{3}{c|}{ Minimum $(\mathrm{cm})$} & \multicolumn{3}{c|}{ Maximum $(\mathrm{cm})$} & \multicolumn{3}{c|}{ N } \\
\cline { 2 - 15 } & MM & CS & S & MM & CS & S & MM & CS & S & MM & CS \\
\hline Fen, marsh & 16 & -29 & $*$ & -74 & -95 & $* *$ & 18 & 2 & $*$ & 24 & 21 \\
\hline Wet meadow & -20 & -41 & $* * *$ & -63 & -108 & $* * *$ & 1 & -6 & $*$ & 29 & 28 \\
\hline Steppe & -92 & -98 & ns & -125 & -164 & $* * *$ & -83 & -67 & $*$ & 12 & 9 \\
\hline Alkali vegetation & - & -47 & - & - & -116 & - & - & -7 & - & 0 & 17 \\
\hline Transitional & & & & & & & & & & 18 & 24 \\
\hline
\end{tabular}

The minus values mean the water level below the surface, and the plus values above the surface. The significant differences (according to t-probe) of the study sites are indicated: ${ }^{*} \mathrm{p}<0.1,{ }^{* *} \mathrm{p}<0.01, * * *$ $\mathrm{p}<0.0001$. N: number of the plots.

month of the study period there were no surface water in the studied areas, but in the wettest month 18 and $2 \mathrm{~cm}$ deep water was on the plots with fen or marsh vegetation. In the wet meadow plots the maximal water level was near to the surface, but in the driest month it dropped 63 or $108 \mathrm{~cm}$ below the surface. The water level in the plots with alkali vegetation is similar to the plots of wet meadow stands.

\section{Hydrological conditions}

The studied areas are situated near to the midline zone of groundwater flow system regionally, but they bear marks of discharge zone locally. If we take into consideration the potentiometric level of the shallow groundwater as upper boundary condition in our model, than the studied areas behave as discharge areas. The difference between the investigated areas lies in groundwater travel paths: while CS belongs to the intermediate flow system, till MM belongs to the local flow system (Fig. 1).

According to the pressure-elevation profile computed from the data of deep wells situated in similar elevation and position than the two studied sites the vertical pressure gradient is similar to the hydrostatic gradient (Fig. 2). This indicates through-flow system. But in the surroundings of CS region the gradient is higher than the hydrostatic one from the depth of -500 (a.s.l.) $\mathrm{m}$ downward, thus the direction of vertical movement of the water is upward in this zone.

Reactions of the four wells to the precipitation were analysed by crosscorrelation. Fig. 3 shows, that CS-1 well responds to changes in precipitation immediately and with a 22-23 days delay. This phenomenon was detected in the case of the other three wells too. It is supposed that the beds near to the well allow the quick infiltration of rainwater into the soil, and a pressure front of the groundwater stream reaching the area of well after 22-23 days after rainfall.

\section{Long term regional changes of groundwater level}

We used long term data of two observation wells with similar elevation and position of the studied sites for evaluation of the former hydrological situation of them. The well no 2421 is near to the MM site, 

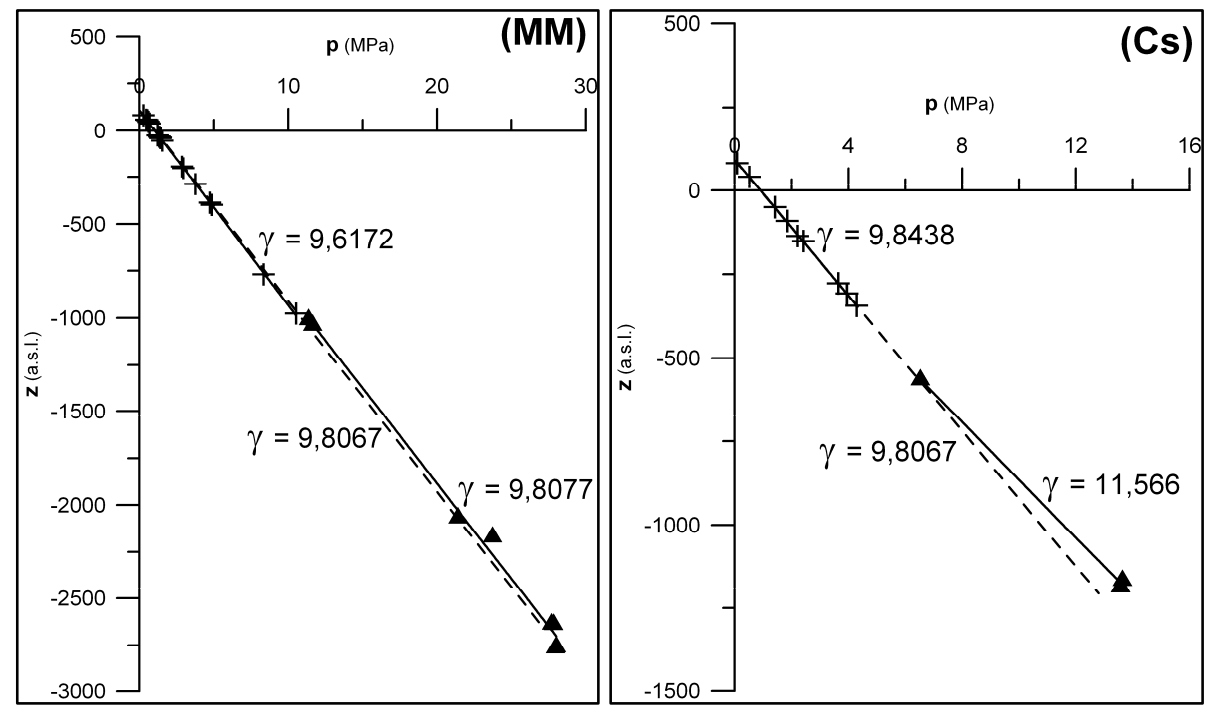

FIGURE 2. Pressure-elevation profiles of studied areas. $\gamma 1,2$ : vertical pressure gradient; dashed line: hydrostatic gradient: $\gamma=9.8067$

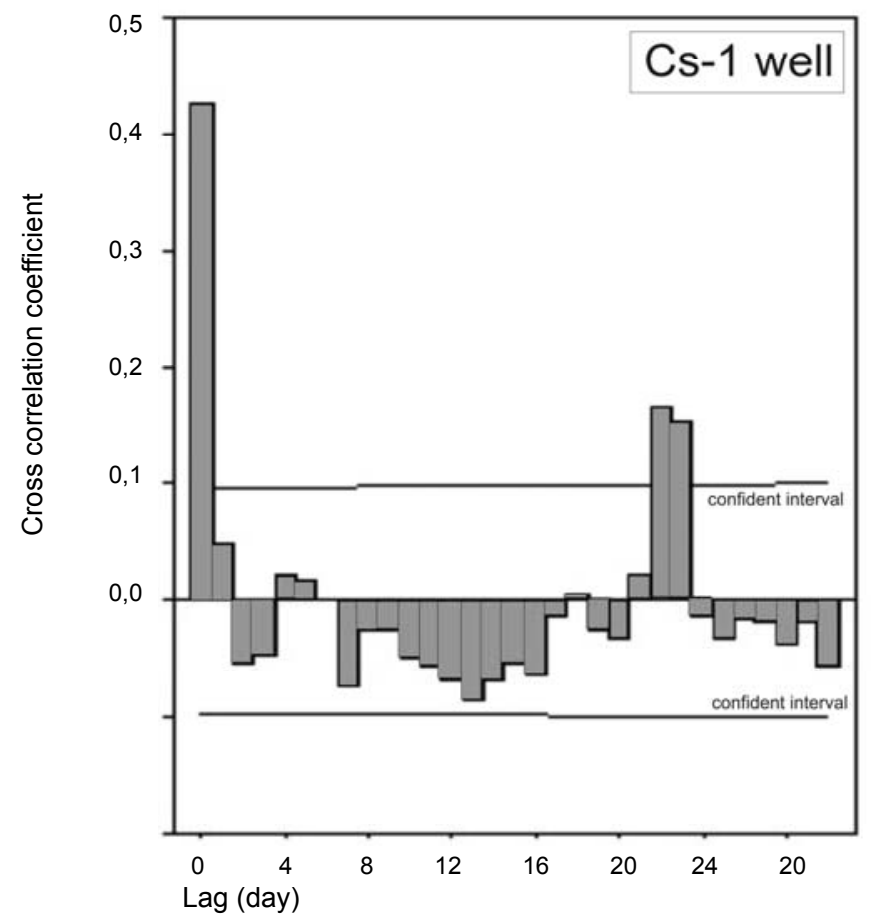

FIGURE 3. Cross-correlation coefficient between groundwater level in the wells and previous precipitation 
and the well no 2422 is near to the CS site. In the region of MM site there was a considerable (more than $2 \mathrm{~m}$ ) drop of the groundwater level from 1980 until 2003. In the region of CS the drop was only $50 \mathrm{~cm}$, and continued from 1983 until 1995 (Fig. 4). The yearly average in the relatively wet 2005 year the groundwater level seemed to be higher than in the CS site, where the vegetation zonation did not changed recently. The typical groundwater levels of the CS site vegetation zones are in good agreement with that of described by Borhidi and

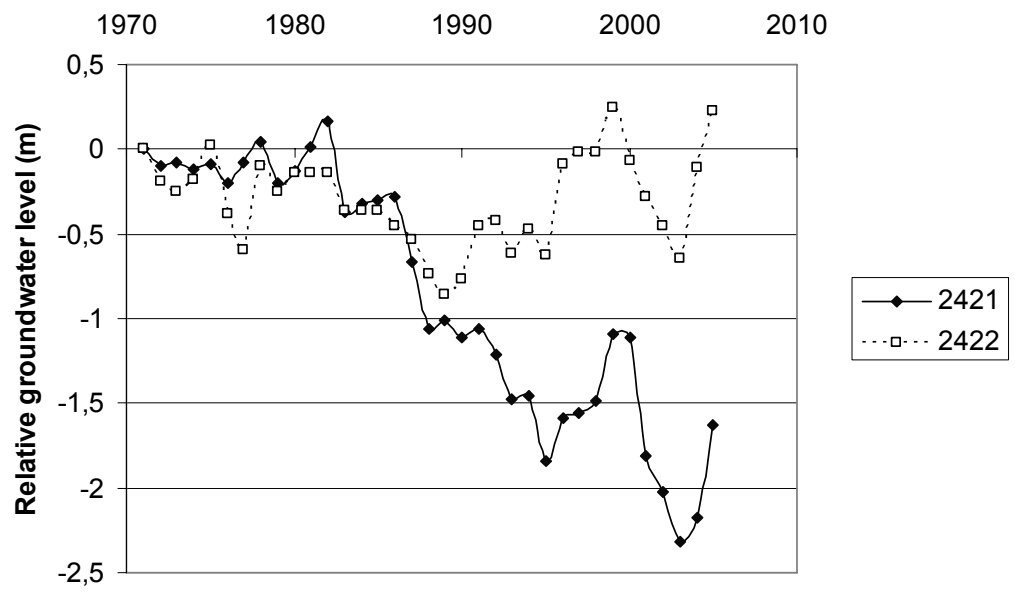

FIGURE 4. Long term relative change of the groundwater level after 1970. The well no 2421 is near to the MM site, and the well no 2422 is near to the CS site

of the groundwater level was about 70 cm higher in 2005 than in 2003.

\section{DISCUSSION}

We characterised the vegetation and the hydrological conditions of two dune slack meadow with high natural values. The groundwater level was $20-40 \mathrm{~cm}$ higher in the MM sites comparing to the same vegetation zone of the CS site. The possible reason of this would be the difference in the long term groundwater dynamic.

Perhaps the vegetation zonation in the MM site followed the strong decrease of groundwater level; consequently,
Sánta (1999).

Fen vegetation is determined by hydrological conditions in an indirect way, and it occurs in discharge zones of river valleys (Wassen, 1990, Kotowski et al., 2001). Fen vegetation is present in the studied dune slack meadows, and we have shown, that these meadows are in discharge zones as well.

In the CS site not only fen, but alkali vegetation was present as well. Recently Molnár and Borhidi (2003) presented some new views about the origins and landscape history of alkali vegetation. They suppose, that solonetz vegetation has two sources of origin: before and after river regulation. In the southern Kiskunság area the alkali 
vegetation is different, it is so called solontshak, and was not effected very much by river regulation. We suppose that the upward flow plays an important role in salinization, and consequently development of alkali vegetation. With the hydrochemical analyses, presently in progress, we will be able to check our hypothesis, definitely.

\section{CONCLUSIONS}

Now we can answer the questions, raised in the introduction. The yearly average groundwater level in the relatively wet 2005 year was 20 and $41 \mathrm{~cm}$ in the zone of the wet meadow vegetation in the two study sites respectively (the other data see in Table 2).

The groundwater flow system clearly shows discharge zones where dune slack meadows occures. Both the formation of fen and alkali vegetation depends on groundwater discharge, bot in the fen areas the water can flow further, but at alkali areas the water evaporates locally, and salts accumulate here.

In the southern Kiskunság there are several other meadows with similar vegetation than described in this paper. The quick and strong regional hydrological changes, especially the decrease of groundwater level would endanger this valuable vegetation, but certain resistance and plasticity of it is rather possible.

\section{ACKNOWLEDGMENT}

The study was supported by OTKA T/F 042877 grant.

\section{REFERENCES}

ARADI E., MARGÓCZI K., KRNÁCS GY. 2006: Conservation and management of fragmented grasslands. A case study of dune slack meadows in southern Kiskunság Természetvédelmi Közlemények (in press) (in Hungarian with English summary).

BATELAAN O., DE SMEDT F., TRIEST L. 2003: Regional groundwater discharge: phreatophyte mapping, groundwater modelling and impact analysis of landuse change. Journal of Hydrology 275, 86-108.

BORHIDI A., SÁNTA A. 1999: Red book of Hungarian plant associations. TermészetBÚVÁR Press, Budapest (in Hungarian).

CHIANG W-H., KINZELBACH W. 1996: 3D-GroundwaterModeling with PMWIN. Springer-Verlag Berlin, Heidelberg, New York.

FEKETE G., MOLNÁR ZS., HORVÁTH F. (eds.) 1997:Descriptionand determination of Hungarian habitats and the National Habitat Classification System. MTTM, Budapest (in Hungarian).

KOTOWSKI W., van ANDEL J., van DIGGELEN R., HOGENDORF J. 2001: Responses of fen plant species to groundwater level and light intensity. Plant Ecology 155, 147-156.

MAJOR P, NEPPEL F. 1988: Groundwater decrease in the Danube-Theiss Interfluve Vízügyi Közlemények 70, 506-623, (in Hungarian).

MARGÓCZI K. 2001: Application of vegetation science in nature conservation. Unpublished $\mathrm{PhD}$ Thesis. University of Szeged, Department of Ecology, (in Hungarian with English summary).

MOLNÁR ZS., BORHIDI A. 2003: Hungarian alkali vegetation: Origins, landscape history, syntaxonomy, conservation. Phytocoenologia 33, 377-408.

TÓTH J., ALMÁSI I. 2001: Interpretation of observed fluid potential patterns in a deep sedimentary basin under tectonic 
compression: Hungarian Great Plain, Pannonian Basin. Geofluids 1, 11-36.

WASSEN M.J., BARENDREGT A., PALCZYNSKI I., DE SMIDT J.T., DE MARS H. 1990: The relationship between fen vegetation gradients, groundwater flow and flooding in an undrained valley mire at Biebrza, Poland. Journal of Ecology 78, 1106-1122.

Streszczenie: Tto hydrologiczne roślinności obniżeń międzywydmowych obszaru Kiskunság. W południowej części obszaru Kiskunság roślinność naturalna (stepu piaszczystego, łąk bagiennych, torfowisk niskich lub mokradeł mineralnych oraz roślinność alkaliczna) zachowała się na łąkach w obniżeniach międzywydmowych (dune slack meadows DSM). Roślinność tych łąk charakteryzuje się dużą bioróżnorodnością oraz wysokimi wartościami przyrodniczymi. Głównym celem poniższego opracowania jest poznanie i określenie warunków hydrologicznych, tak aby wspomóc działania służące ochronie wartości przyrodniczych na tym obszarze. Badania terenowe przeprowadzono na dwóch obszarach łąk obniżeń międzywydmowych (obszary oznaczone MM i CS). Zakres badań obejmował określenie składu gatunkowego roślinności, instalacje studni (piezometrów) wód gruntowych. Dodatkowo wykorzystano dane $\mathrm{z}$ istniejących studni wód gruntowych, zlokalizowanych $\mathrm{w}$ analogicznych warunkach, w celu określenia tła hydrologicznego dla znajdującej się na tych obszarach roślinności. Charakterystyczne wartości położenia zwierciadła wód gruntowych dla tych samych typów roślinności w 2005 roku, który był stosunkowo wilgotny, były wyższe w przypadku obszaru MM niż dla obszaru CS. Przypuszczalnie jest to wynikiem wcześniejszych zmian roślinności spowodowanych wyraź- nym spadkiem położenia zwierciadła wód gruntowych w regionie, w którym znajduje się obszar MM. Analiza wyników modelu hydraulicznego sytemu wód gruntowych wskazuje, iż obydwa obszary badawcze znajdują się strefach drenażu wód gruntowych. Sądzimy, że taki wznoszący ruch wody odgrywa istotną rolę $w$ rozwoju roślinności alkalicznej w obszarze CS. Współczynnik korelacji pomiędzy stanami wód gruntowych a opadami poprzedzającymi wskazuje na szybką infiltrację wód opadowych w głąb profilu glebowego, oraz na docieranie wód opadowych na obszar lokalizacji studni wód gruntowych po okresie 22-23 dni od chwili wystapienia opadu. Szybkie i wyraźne regionalne zmiany hydrologiczne, a w szczególności spadek położenia zwierciadła wód gruntowych, mogą stanowić zagrożenie dla wartościowych typów roślinności na tym obszarze. Jednakże, występująca tutaj roślinność charakteryzuje się również pewnym potencjałem odporności i przystosowania się do ewentualnych zmian o takim charakterze.

\section{MS. received November 2007}

\section{Authors' addresses:}

Katalin Margóczi, Eszter Aradi

Department of Ecology, University of Szeged, Egyetem u. 2. Szeged, H-6701 Pf. 51., margoczi@bio.u-szeged.hu

János Szanyi

Hungarian Geological Survey, Sóhordó u. 20. Szeged, H-6721 Hungary

szanyi@iif.u-szeged.hu

Bertalan Busa-Fekete

Department of Mineralogy, Petrology and Geochemistry, University of Szeged, Egyetem

u. 2. Szeged, H-6701 Hungary

busa@geo.u-szeged.hu 